\title{
THE ESSENCE AND MAIN CHARACTERISTICS OF NATIONAL-PATRIOTIC UPBRINGING: THEORETICAL ASPECT
}

\author{
Elena Fedorenko \\ Department of social work, social pedagogy and pre-school education in Melitopol State \\ Bogdan Khmelnitsky Pedagogical University \\ 20 Getmanska str., Melitopol, Ukraine, 72300 \\ elenka.fedorenko@gmail.com
}

\begin{abstract}
The article contains the results of a study of the nature and main characteristics of the national-patriotic upbringing. The study was conducted by studying and analyzing the latest regulations and publications, related issues and identifying the nature of the main characteristics of the national-patriotic upbringing. The author of the article presents the results of scientific analysis, conclusions about the need to develop formation technologies of national-patriotic education of students at schools.

National-patriotic upbringing is a complex of personality traits and actual result, achieved by an individual or collective in the process of national-patriotic upbringing, manifested in the ability and willingness to be realized as an individual and collective in the service to the Motherland: learning the experience of cognitive activity by a student involves the formation of patriotic knowledge and ideas; mastering the experience of emotional and value relationships by a student means the formation of patriotic feelings, values, beliefs; mastering the student's practical experience is manifested in the implementation of patriotic knowledge and ideas, values and beliefs in patriotic behavior and activities.

The essence of national-patriotic upbringing, in our opinion, is the students' learning of the experience of cognitive activity, emotional-value relationships and effective practical experience, which are manifested in the ability and willingness to be realized as an individual and collective in the activity for the benefit of the Motherland.
\end{abstract}

The article can be recommended for publication in a specialized journal.

Keywords: upbringing, behavior, national and patriotic upbringing, national-patriotic behavior.

DOI: $10.21303 / 2504-5571.2019 .001008$

\section{Introduction}

Under the conditions of inadequate efforts of the state in politics of consolidation of society, the lack of an effective mechanism of formation and implementation of public policy and lack of relations with civic society in national-patriotic education in the formation of active citizenship and national-patriotic consciousness of citizens of Ukraine, who'll cherish Ukrainian traditions and spiritual values, have appropriate knowledge, abilities and skills, able to realize their potential in today's society are urgent.

In the field of national-patriotic upbringing of children and youth should be developed authorized central executive bodies with participation of scientists and independent experts, taking into account the best international practices of successful democracies and introduced common standards, including the means and principles of forms and methods of national-patriotic upbringing, evaluation of achievements of relevant subjects in this area and their expertise [1].

\section{Directions goal Strategy}

- Study of modern educational systems, technologies and techniques in the field of national-patriotic education, synthesis and dissemination of best practices in this area;

- Introduction of subjects of spiritual and moral orientation as the basis of identity formation and basis for national-patriotic upbringing;

- Formation of unified standards in the field of national-patriotic education tools and their implementation;

- Raising the professional competence of specialists in the national patriotic education, establishing constructive interaction among the subjects of national-patriotic education [1]. 
The analysis of recent researches, related to issues of identifying the nature and main characteristics of the national-patriotic upbringing, proves that the formation of national and cultural identity, national-patriotic ideology, preservation and development of spiritual and moral values of the Ukrainian people is one of the key factors, which influence the formation of self-sufficient citizen-patriot of Ukraine, humanist and democrat, ready to perform civil and constitutional responsibilities to the succession of spiritual and cultural heritage of the Ukrainian people, to achieve high cultural relations.

The idea of the importance of an effective educational system of national-patriotic education has been long established and reflected in studies of philosophers and scientists-teachers mainly in terms of the analysis of such approaches as systematic (M. Antonets, A. Boyko, L. Vovk, etc.), cultural (Yu. Bondarenko, O. Vyshnevskyy, V. Dovbyschenko, etc.) and civilization (H. Vaschenko, B. Grinchenko Hrushevsky, etc.).

Problems of national-patriotic education were highlighted at the end of the twentieth century and attracted the attention of both teachers and psychologists, including B. Ananiev, Blonskii, L. Vygotsky, G. Kostiuk, A. Leontiev, Alexander Petrovsky, Mr. Jacobson.

Among modern scholars, working on issues of patriotic education and civic personality traits, I. Bekh defines patriotic education to guide individual identity formation, as a patriot, which involves the formation of positive values (cognitive and emotional) attitude to the Motherland [2, p. 48], P. Verbitskaya explored modern development aspects of civic education of youth [3, p. 384], P. Ignatenko in his scientific and methodical manual "Educating citizen: psychological and pedagogical aspects and ethnology" determined that there are major psychological and pedagogical aspects of ethnology and patriotic education [4. p. 252], Yuri Rudenko has shown that patriotic ideology is the foundation of spirituality of students [5], K. Black argues that the patriot - is someone who in today's field of unlawful excesses promotes the development of a democratic social state by legal methods. He/she does not identify Ukraine, the state, with the government, but is aware that the government should be only the mechanism, means to implement the people's will, not the owner [6]. O. Shestopalyuk, based on a systematic study, concluded that the most appropriate method of civic education of students is the synthesis of developments in pedagogy, history, psychology, sociology, and other sciences methodology regarding civic education and training and the integration of relevant knowledge [7] and others.

Various aspects of the formation of national-patriotic upbringing are revealed in the works of N. Snopko, N. Voloshin and others; namely determination and justification of national-patriotic education of students, which aims at the formation of high patriotic consciousness, willingness to perform civil and constitutional duty to protect the interests of the homeland, commitment to the state sovereignty of Ukraine.

Aim of research is to identify the nature and main characteristics of the national-patriotic upbringing.

Object of study is the educational process in schools of education.

Subject of investigation is the nature and main characteristics of the national-patriotic upbringing.

\section{Materials and methods}

The methodology of the study is to analyze and systematize the philosophical, cultural, psychological and educational literature on the formation of national-patriotic education of students in secondary school; summarizing the scientific literature on national and patriotic issues; induction, deduction, synthesis, comparison and comparison of ideas, the concept of national-patriotic education, theory of education in national self-assertion of youth; the principles and patterns of national-patriotic education of students in secondary schools and more.

\section{Result}

According to the strategy of education development in Ukraine until 2021 one of the important ways to implement national-patriotic education of youth is the formation of its scientific and theoretical and methodological principles: 
- development and implementation of national-patriotic education of young people in educational institutions;

- learning needs of young people, especially through sociological research.

The school must evolve and keep pace with the progress of life, find new ways to optimize the modern national-patriotic education. It should provide its students with the possibility of expanding personal perspectives in accordance with democratic and pluralistic tendencies of society. However, the limited capacity of school is material, organizational, cultural, technological, ideological and other social factors. To overcome this limitation is possible only through the establishment of school interaction with other elements of socialization - family, community, church, media production organizations.

All this requires a certain reassessment of the situation in the Ukrainian system of national-patriotic education of children and young people to find new principles and approaches of national-patriotic education of the individual, the entry into the main components of the national-patriotic education, national and cultural identity, national patriotic ideology, preservation and development of spiritual and moral values of the Ukrainian people and so on. Consequently, the crystallized complex is an aspect of children, acquiring national and patriotic upbringing as a component of human spiritual values. In terms of modernization of contemporary Ukrainian education we should actively tackle a number of issues of profound transformation, including issues, relating to clearly define the new priorities in the education of young people; implement a phased plan of complex measures on the development of basic spiritual and moral values, culture and international communication, based on the principle of tolerance, respect for traditions and customs of the peoples of our country.

Study of philosophical, sociological, psychological and pedagogical literature made it possible to identify global trends in the implementation of the tasks of the national-patriotic education of children and youth, namely found that there are different approaches to the definition of "patriotism". So in the Great Dictionary of the modern Ukrainian language this concept is defined as "love of country, devotion to it and to its people, the willingness to come to its defense", and "patriot - a human, who loves his/her Motherland, loyal to his/her people, ready for them to sacrifice and deeds" [8, p. 894].

Determining this interpretation is the emotional and sensual sphere of personality categories: love, commitment, willingness. Philosophy interprets the concept as something moral and political principle, the content of which includes love for the Motherland, pride in its past and present, devotion to the interests of their country and the desire to protect it [9].

Historical and philosophical aspect of patriotism involves consideration of it as a social and historical phenomenon, due to socio-political, economic, ethno-cultural and other characteristics of a particular society. Note that the problem of patriotic education and its role in shaping the human drew attention of many Ukrainian thinkers from different generations and views from the Kievan Rus to the present.

Famous Ukrainian philosophers-thinkers, such as H. Skovoroda, T. Shevchenko, P. Yurkewych, K. Ushinsky, I. Franko, O. Dukhnovych, J. Chipiga, in their writings mark patriotism, diverted to Ukrainian people, namely love of the Motherland, to native language, to its people; respect for the historical past; the formation of national consciousness. In his philosophical and literary works H.Skovoroda examines the problems of human studying and his/her existence. His outlook has patriotic and religious-philosophical nature. The main Shevchenko's slogan is the phrase "Love Ukraine as a mother." This philosophy is deeply individual, personal and the same time, the idea was based on a national Ukrainian idea, its mentality. Actually Shevchenko's philosophy comes up from the patriotic love for their native land, awakening of human dignity, sorrow, regret, desolate life, force of protest and re-bellion [10, p. 77].

The philosophical foundations of the educational process in accordance with the new paradigm of education were researched by such Ukrainian scientists as M. Antonets, A. Boyko, L. Wolf, M. Evtukh, P. Kononenko, B. Moskalets, M. Stelmahovych, M. Yarmachenko and others.

The problem of the essence of patriotic consciousness is reflected in the national philosophy of education (A. Bychko, I. Nadolniy, L. Sokhan) and foreign philosophy (I. Kant, K. Rogers, Erich 
Fromm and others). In the works of modern Ukrainian researchers V. Andrushchenko, I. Bekh, V. Koval, V.Kulchytskyy and others.

The problem of democratic and national-patriotic education of philosophical and anthropological accents is revealed. Social and philosophical dimension of patriotism contemporary Ukrainian society was studied by N. Voloshina [11].

Theoretical aspect of patriotic education is developed by the following classics of Ukrainian pedagogy: H. Alchevska, G. Vashchenko, B. Grinchenko, M. Hrushevsky, A. Dukhnovych, M. Drahomanov, A. Makarenko, I. Ohiyenko, S. Rusova, V. Sukhomlinsky, K. Ushinsky. In their opinion, considerable attention in the formation of patriots should be paid to the education of love for their land, mother language, formation of national identity.

The idea of the formation of human, his/her world view, launched by V.O. Sukhomlinsky, is most evident in the patriotic education, which, according to the teacher, is an area of spiritual life which penetrates all knowing, doing, all that a person loves and hates [12, p. 29].

V. Sukhomlinsky created a fundamentally new system of education, the center of which put a student as the subject of education, directing nurturing his/her inner peace, spirituality. In particular, the scientist built the whole process of patriotic education in adolescence on psychological basis of gradual transition from external regulators of teen activity in the domestic determinants of his/her behavior and activities. Formation of patriotic education and the same beliefs and ideals is based on the psychological aspects: understanding adolescent moral values; awareness and experience of moral concepts in real relationships with people; teen subjective attitude to truth and perception of socially important moral values into the field of personally meaningful; adolescent psychological readiness to act in accordance with the beliefs in the ideals that form; motivated acts of moral satisfaction of adolescents and their results in the development of moral consciousness. The particular emphasis was placed by the scientist to develop feelings of love, responsibility, obligation, duty to his/her people and to stage teenager personal problems before his/her own conscience in the selection of moral behavior on their homeland. V. O. Sukhomlinsky's vision of harmonious education as a process of opening innate properties of a child in a specially organized society is deeply reflected in his works of the last decade. The strength and effectiveness of patriotic education after V. O. Sukhomlinsky are determined by how deeply the idea of homeland enters the spiritual world of the adolescent period of his/her development as a person and citizen, how deeply he/she sees the world and him/herself by patriot eyes [9, p. 31].

Psychological mechanisms of formation and development of personality, which the patriotic education is based on, were explored by B. Ananiev in his writings [13]. Mr. Blonsky believed that education is "... deeply national" [14]. L. Vygotsky still told about the significant influence of culture on mental life, noting that it, culture, creates a specific behavior. Culture can alter the activity of mental functions, overbuilding new floors in the structure of human behavior. An evidence of this is the process of historical development in which social human transforms natural inclinations and functions, produces and creates new behaviors that are specific cultural [15].

O. M. Leontyev elaborated a number of provisions of L. Vygotsky. In particular, he proved that an individual assigns him/herself to mental development achievements of previous generations in their own historical plays of human abilities. The essential characteristic of appropriation abilities is that it is carried out only by a child in joint activities with adults, to communicate with them and under their direction, and in common with other children [16].

Nonlinear development, according to G. Kostyuk, is the dynamics of the mental qualities in the process of education. Built on a scientific basis, this process actively promotes mental development of students [17].

O. Petrovskyy in his textbook for students of higher educational institutions pointed out that the problem of selection and formation needs together forms a system of human aspirations that is one of the most important tasks of education [18].

For the proper construction of the educational process, as P. M. Jacobson mentioned, an adult must be informed, about the content of the student's emotional sphere, how students of all ages react in relation to his parents, teachers and peers [19]. 
Among modern scholars, working on issues of patriotic education and civic personality traits, I. Bech, P. Verbitskaya, P. Ignatenko, A. Pogribnyy, Y. Rudenko, K. Chorna, A. Shestopalyuk and others.

Modern psychological science (I. Bech, P. Gnatenko, A. Kyrychuk, N. Mihalchenko, V. Pavlenko, S. Tahlin) studies the mechanisms of internalization of social processes and phenomena that influence the formation patriotic qualities of personality. A personality value of patriotism is generated by persistent human experience of love to the nearest and remote environment, in which he/she is located, and what is important to him/her [20, p. 9].

I. Bech defines patriotic education, to guide individual identity formation as a patriot, which involves the formation of positive values (cognitive and emotional) attitude towards the Motherland. Mental structure of human relations is a unique fusion of cognitive and emotional structures, where the last component is considered the leading [21].

V. Miroshnichenko, studying the psychological aspects of patriotic education, argues that the attitude of an individual to the Motherland reflects his/her social and psychological position. The author is associated with the attitude characteristic of mind as mentality. Mentality creates an opportunity for a person to identify with certain people, certain culture that reveal his/her mentality. Mentality is the philosophical and psychological basis of patriotism, as formed in the process of comparing cultures of different civilizations [22].

After N. M. Snopko, ideals of patriotic education in spiritual values can serve ethical, aesthetic and artistic cultures and characteristics of a person - mind, will and other abilities that are reflected in the different activities [23].

Other researchers also point out on the importance of objective consideration of teacher's psychological mechanisms of motivational-value sphere of personality: his/her feelings, needs, beliefs, values, character traits, and. Mechanisms of education are understood as ways of the motivational-value sphere of an individual in the process of mastering his/her social experience.

The problems of patriotic education to date are investigated by I. Bech and N. Chorna, who noted that during the years of independence, Ukraine created conditions for updating content and technology of patriotic education, formation of humanistic values and citizenship of the younger generation. In the center of patriotic educational process is a human personality as the highest value. The basis of the system of patriotic education is to put the national idea as a consolidating factor in the development of society [21, p. 3].

1. Patriotism is considered by the authors as a social and individual value component of the personality structure. Patriotism is the love to the country, people and concern for their benefit, promotes the establishment and strengthening of Ukraine as a sovereign, legal, democratic, social state, the willingness to defend its independence, to serve and protect her, to share own fate with her fate [21, p. 23].

The pedagogical dictionary says that patriotism is the love the country, devotion to its willingness, to serve its interests, readiness to sacrifice. Patriotism is manifested in practical activities, aimed at the comprehensive development of the country, protection of its interests. The education of patriotism of children begins with instilling in them love for their native language, culture, people, and traditions, respect for family relics, related to labor and military aspects of life of ancestors, relatives, fellow [24, p. 134].

2. In the philosophical dictionary patriotic education is seen as education, the content of which is love for one's homeland, loyalty, and pride in its past and present, desire to protect the interests of the Motherland. This definition updates the role of patriotic education, because it is through active human activities for the public found his/her true feelings. This training will include love for the Motherland and national identity and dignity; respect for the native language, culture and traditions; responsibility for the nature of their country; the need to contribute to the fate of the Motherland; interest in international communication; desire to work for the good of their country and its people. It has application both in the family and school, and in state and public organizations, based on confidence in the positive effect of the same ratio. Based on this understanding of the concept of "patriotic education", its subject categories are national idea; national culture; native language; 
history of the people and the state; self-identity; category Motherland (Homeland small and large); leaders and heroes of the people, nation, State; native land, city, village; family; mother, father. The result of patriotic education can be considered a person, a citizen or representative of a nation or nationality, who: understands and shares the essence of the national idea; a carrier of national culture; their profession contributes to the economic, scientific and cultural growth of the Motherland; loves and defends his/her native language, uses it; loves, protects and defends his/her native country/state/ territory; loves, protects and defends its customs and traditions; loves, protects and supports citizens with a patriotic way of thinking; always feels proud of belonging to these categories.

O. Stiopina has her own views on the essence of patriotism that defines the phenomenon investigated as an integral value and spiritual and moral quality of an individual, resulting in a feeling of love for the Motherland and the sense of spiritual connection with it, the moral responsibility for the fate of the Motherland and readiness to defend, free of ethnic and national self-determination, conscious preservation and enhancement of national spiritual and material values [25, p. 12].

3. Analysis of different approaches to the definition of national-patriotic education allowed Zubtsova to identify the following aspects of this process:

1) formation of a sense of patriotism: the ratio of the Motherland, the people, the society, the moral sense, due to the outlook of people, their affiliation to the ethnic community;

2) education of patriotism as one of the most powerful and permanent motives of social activity;

3) forming a system of views and ideas, resulting from the assimilation of cultures, traditions and customs of its people;

4) formation of patriotism as a direct manifestation of love for the Motherland in the actions of people, the ability to self for the good of the Matherland.

Summarizing the modern scientific approaches of V.Harniychuk, V. Dzyuba, K. Zhurba, E. Zaredinova, V. Kirichek, A. Korkishko, K. Chorna and other researchers to determine the nature of the concept of "patriotic quality," Y. Zubtsova established: patriotic quality personality is a socio-psychological property that appears in the unity of knowledge and activity-individual feelings about the world of people, surrounding the subject of the environment and society as a whole [23, p. 9].

R. Petronhovsky determines such criteria and indicators forming the national-patriotic upbringing:

- cognitive (understanding the attributes of the state, rights and obligations);

- ethnic identity (understanding unity of the Ukrainian ethnic group in the knowledge of the customs and traditions of the native people, their difficult destiny and historical perspective prediction of its progressive growth);

- emotional motivation (the desire to be included in the training activities, subject-transformative activities and activities, aimed at preserving the historical memory of their land, cultural monuments, honoring prominent people of the region);

- practical (detection of cognitive, search, organizational, subject-transformative abilities and skills of subject - object interaction as the foundation of patriotic habits) [26, p. 11].

The national-patriotic education is a set of personality traits and actual results, achieved by an individual or team in the national-patriotic education, manifested in the ability and willingness, realized by a personality and individuality in service to the Motherland:

- learning experience cognitive activity by a student involves the formation of patriotic knowledge and understanding;

- learning experience of emotional and value relationships by a student means formation of patriotic feelings, values and beliefs;

- learning effective and practical experience by a student in implementing turns into patriotic knowledge and understanding, values and beliefs of patriotic behavior and activity.

\section{Conclusions}

The essence of the national-patriotic education, in our opinion, is learning by students experience cognitive activity, emotional relationship of effective and practical experiences that are in 
the ability and willingness, realized by a personality and individuality to the benefit of the Motherland.

Prospects for further research in the development of technologies are seen in the formation of national-patriotic education of students of secondary schools.

\section{References}

[1] Stratehiya natsionalno-patriotychnoho vykhovannia ditei ta molodi na 2016-2020 roky: zatverdzheno Ukazom Prezydenta Ukrainy vid 213 zhovtnia 2015 r. No. 580/2015 (2015). Klasnyi kerivnyk, 30/31, 6-22.

[2] Bekh, I. D. (2006). Vykhovannia osobystosti: Skhodzhennia do dukhovnosti. Kyiv: Lybid, 272.

[3] Verbytska, P. V. (2009). Hromadianske vykhovannia uchnivskoi molodi: suchasni aspekty rozvytku. Kyiv: Heneza, 384 .

[4] Ihnatenko, P., Popluzhnyi, V., Kosarieva, N., Krytska, L. (1997). Vykhovannia hromadianyna: psykholoho-pedahohichnyi i narodoznavchyi aspekty. Kyiv: Instytut zmistu i metodiv navchannia, 252.

[5] Rudenko, Yu., Rudenko, V. (1999). Ideolohiya patriotyzmu i derzhavotvorennia yak osnova dukhovnosti uchniv. Ridna shkola, $10,8-10$.

[6] Chorna, K. (2008). Natsionalna ideia yak faktor stanovlennia patriotyzmu u ditei ta molodi. Shliakh osvity, 3, 5-11.

[7] Shestopaliuk, O. V. (2008). Hromadianske vykhovannia maibutnikh uchyteliv: teoretychni i metodychni elementy. Vinnytsia: Vydavnytstvo «Konsol», 260.

[8] Bules, V.T. (Ed.) (2004). Velykyi tlumachnyi slovnyk suchasnoi ukrainskoi movy. Kyiv: Irpin: VTF «Perun», 1440.

[9] Shynkaruk, V. I. (Ed.) (1986). Filosofskyi slovnyk. Kyiv: Holov. red. URE, 800.

[10] Kulchytskyi, V. Y. (2014). Filosofsko-svitohliadni peredumovy rozvytku patriotychnoho vykhovannia v Ukraini (istorychnyi aspekt). Naukovyi visnyk Uzhhorodskoho natsionalnoho universytetu. Seriya pedahohika i sotsialna robota, 30 , $76-78$.

[11] Voloshyna, N. M. (2010). Sotsialno-filosofskyi vymir patriotyzmu suchasnoho ukrainskoho suspilstva. Kyiv, 20.

[12] Sukhomlynskyi, V. O. (1976). Narodzhennia hromadianyna. Vol. 3. Kyiv: Rad. shkola, 283-567.

[13] Ananiev, B. H. (1980). Vybrani psykholohichni pratsi. Vol. 1. Vol. 2. Mosow: Pedahohika, 230, 288.

[14] Blonskyi, P. P. (1964). Obrani psykholohichni tvory. Moscow: «Prosveshchenye», 547.

[15] Vigotskiy, L. S. (1991). Pedagogicheskaya psihologiya. Moscow: Pedagogika, 480.

[16] Leont'ev, A. N. (1983). Izbrannye psihologicheskie proizvedeniya. Vol. I. Moscow: Pedagogika, 392.

[17] Kostiuk, H. S. (1976). Vikova psykholohiya. Kyiv: Radianska shkola, 266.

[18] Petrovskiy, A. V., Yarosheeskiy, M. G., Brushlipskiy, A. V., Petrovskiy, V. A. (1998). Obshchaya psihologiya. Moscow: Izdatel'skiy tsentr Akademiya, 512.

[19] Yakobson, P. M.; Borisova, E. M. (Ed.) (1998). Psihologiya chuvstv i motivatsii. Moscow: In-t prakt. psihologii Voronezh NPO «MODEK», 304.

[20] Zubtsova, Yu. Ye. (2012).Formuvannia patriotychnykh yakostei molodshykh shkoliariv u vzaiemodiyi shkoly ta simi. Kyiv, 21.

[21] Bekh, I., Chorna, K. (2008). Natsionalna ideia u vykhovnomu protsesi shkoly: prohramno-vykhovnyi kontekst. Shkilnyi svit, 45, 1-13.

[22] Miroshnichenko, V. I. (2012). Systema patriotychnoho vykhovania maibutnikh ofitseriv-prykordonnykiv. Khmelnytskyi: Vydavnytstvo Natsionalnoi akademiyi Derzhavnoi prykordonnoi sluzhby Ukrainy imeni B. Khmelnytskoho, 376.

[23] Snopko, N. M. (2007). Psihologicheskie mehanizmy i pedagogicheskie osnovy patrioticheskogo vospitaniya v sisteme professional'nogo obrazovaniya. Moscow, 34.

[24] Aleksieienko, T. F., Artemova, L. V., Bahlaieva, N. I. (2002). Pedahohichnyi slovnyk dlia molodykh batkiv. Kyiv, 244.

[25] Stopina, O. H. (2007). Vykhovannia patriotyzmu u studentskoi molodi zasobamy mystetstva. Luhansk, 23.

[26] Petronhovskyi, R. R. (2002). Formuvannia patriotyzmu starshoklasnykiv u pozanavchalniy vykhovniy diialnosti. Kyiv, 21. 